\title{
Market Orientation and Innovators' Success: an Exploration of the Influence of Customer and Competitor Orientation
}

\author{
Michael Lewrick', Maktoba Omar², Robert L.Williams, Jr. ${ }^{3}$
}

\begin{abstract}
The concepts of market orientation and innovation and their interrelationship with business success have been explored from a number of perspectives. However, research in this area has not explored the differences between start-up and mature companies. The research study acquired data from over two hundred Chief Operating Officers (CEO's) and Managing Directors from both start-up and mature companies. The results illustrate the differences in both types of company and reveals new insights with regard to market orientation and its constituent elements and its relationship with both incremental and radical innovations. Key research results are that strong competitor orientation, a key ingredient of market orientation, has positive relationship to incremental innovation for start-up companies but it is contra productive for mature companies. In mature organizations a strong customer orientation is associated with radical innovation.
\end{abstract}

Keywords: Innovation; market orientation; customer orientation; competitor orientation.

\footnotetext{
' Munich University of Applied Sciences, Department of Business Administration,Am Stadtpark 20;8I 243 Munich, Germany Email:MLewrick@aol.com

2 Edinburgh Napier University, The Business School, School of Marketing, Tourism and Languages, Craiglockhart Campus, Edinburgh, EHI4 IDJ Email:m.omar@napier.ac.uk

${ }^{3}$ Assistant Professor of Marketing, Saint Mary's College, Department of Business and Economics, Notre Dame, IN 46556-500 I

Email: rlwjr@saintmarys.edu
} 


\section{Introduction}

This study investigates the effects of different parameters of market orientation on radical and incremental innovation in both start-up and mature companies. This contrasts to other research in this area as distinguishing between start-up and mature companies yields new insights about the transformation process in the growth of innovative companies. Market orientation is generally recognized as part of the business strategy of companies and it is considered as an important strategic orientation in literature (Hunt and Lambe 2000; Gatignon and Xuereb 1997). The concept of market orientation as a business strategy includes the collection of market relevant information. The information is distributed within the organisation with the aim to align products and services to customer needs. The foundation of this is based on the "marketing concept" (Drucker 1954; Levitt 1960). However, market orientation goes beyond the concept and it is associated with the implementation of this approach (Wren 1997).

To be market orientated implies that the firm embraces a strategy to obtain and use information about the environment and to disseminate this information throughout the firm. As mentioned before, the foundation of the marketing discipline is the "marketing concept" and the origin of this concept is in the focus by the firm on the customer and their needs (Drucker 1954; Levitt 1960).

In the context of this study innovation is measured by three categories: counts of incremental, radical and overall innovation. Incremental innovations are the improvements/expansions of existing products, services, processes, technical or administrative conditions. Incremental innovation does not cause a significant departure from status-quo. In contrast, radical innovations in products, services, processes, etc. are breakthroughs that fundamentally change a product or service or process. Overall innovativeness is the total of all innovations put into practice, radical and incremental in all typologies. These categories have been clearly identified as measures of innovatory activity by a number of authors (Tidd, Bessant and Pavitt 2003: Gatignon et al. 2002; Garcia and Calantone 2002: Utterback 1996). Market orientation can be defined as the organizational culture that most effectively and efficiently creates the necessary behaviors for the creation of superior value for customers and, thus, superior performance for the business (Narver and
Slater 1990). The term market orientation has been used in many directions and often the terms customer focused, market driven, and customer centric have become terms associated with market orientation (Deshpande 1999). Within this study market orientation is considered to consist of four pillars (a) customer centric, (b) customer intelligence, (c) competitor orientation, and (d) market dynamism. A more comprehensive definition of each dimension of market orientation is outlined below.

In the following section a short literature review is given and teases out the definition of the components of market orientation. Afterwards the key questions of the research instrument and research design with two key hypotheses to test in this study are outlined. The link between market orientation and innovation is demonstrated and from this the variation between start-up and mature companies is discussed. Recommendations as to how performance of a firm can be enhanced are then made.

\section{Market Orientation, Innovation and Success}

The positive influence of market orientation to business success has been addressed in several studies (Greenley 1995; Hooley et al. 2000; Langerak 200I; Kahn 200I; Cano et al. 2004; Zhuo et al. 2005; Gainer and Padanyi 2005; Kara et al. 2005; Hult et al. 2005). Lewrick (2009) categorised companies in different performance levels with regard to innovation and business success. The scholar highlights that "A typical low performing company lacks in customer orientation. In many cases the strategy emphasis on a strong product development process without considering the customer needs (Lewrick, 2009:40)" The relationship between market orientation and innovations has been also addressed by studies from Kohli and Jaworski 1990; Rueckert 1992; Slater and Narver 1994; Kwaku 1996; Gatignon and Xuereb; 1997. Kohli and Jaworksi suggest that "market orientation entails: (I) one or more departments engaging in activities geared toward developing an understanding of customers' current and future needs and the factors affecting them; (2) sharing of this understanding across departments; and (3) the various departments engaging in activities designed to meet select customers needs" (I990 p.3). 
The cross-functional share of information and knowledge might trigger invention and streamline the innovation process leading to market success. However, the negative influence of market orientation, especially on radical innovations, has been detected (Bennett and Cooper 1979; Lawton and Parasuraman 1980). Lawton and Parasuraman (1980) revealed in a study that the adoption of the marketing concept did not affect the success of new product ideas in the market or the innovativeness of new product offerings. Other scholars concluded that a strong customer orientation has an negative impact on market success of new products and services (Christensen and Bower 1996; Leonard-Barton and Doyle 1996), while others claim that customer orientation leads to more innovations (Von Hippel 2005). Market and Business opportunities might arise from extensive research and will reach the market push effect, or the market has the need for something different or new - the pull effect. Both approaches (push and pull) might be essential to be innovative and Tidd et al. comment that: "sometimes the "push" will dominate, sometimes the "pull", but successful innovations require interaction between the two" (2003, p.43).

Some studies investigate the market orientation and innovation of new ventures or small firms and their success (Audretsch 2001; Cohen and Klepper 1992; Verbees and Meulenberg, 2004; Hyvonen and Tuominen 2006). Bigliardi et al (2010) for example, revealed in study of SMEs that innovative companies investigate the marketplace, put more emphasis to product enrichment and operate with better systems and technology than less innovative companies. However, little attention has been given to the differences between start-up and mature companies and the change in their behavior over time, i.e. their transition.

\section{Customer Centricity \& Customer Intelligence}

The customer has become recognized as a dominant influence on company strategy and can be defined as a cocreator of value. The extent of the company's interaction with customers can be quantified and qualified by the amount of data collected, analysis of customer needs and information relevant to realize innovations. However, the customers as co-developer for new products and services differ in start-up and mature companies (Lewrick 2004). Kohli and Jaworski (1990) recognized the importance of customer focus, but in their definition market intelligence is at the centre of market orientation. In this conjunction, market intelligence includes ascertaining current and future customer needs, dissemination of the intelligence across departments, and organisation-wide responsiveness to customer needs. They introduce market intelligence instead of customer focus since in their view market intelligence is much broader than customer focus. However, within this study customer centric includes the integration of customer needs and strategies as well as the processes of an organisation. Customer intelligence is the knowledge about the customer which might be collected e.g. by focus groups, surveys and observation. Previous research suggests that understanding customers increases the value of innovation created in the product and service development process. Von Hippel (2005) pointed out that some customers of products might be ahead of the trend and can drive the development of new products. Lukas and Ferrell (2000) also found that customer orientation increases the introduction of newto-the world products and reduces the launching of "metoo products". Hence, it can be hypothesized that market needs drive innovations.

\section{Competitor Orientation}

Organizations that are focused on their competitors are less likely to come up with radical innovations. A strong competitor orientation causes "me-too" products and incremental innovations (Lukas and Ferrell 2000). However, over the last decade more open approaches towards innovation management became popular. For example, Giannopoulou et al. (2010) point out that "Alliances between firms, distributed co-creation practices and collaborations with customers become more and more important (2010:164)" According to Narver and Slater (1990) competitor orientation, as an element of market orientation, means that "a seller understands the short-term strengths and weaknesses and long-term capabilities and strategies of both the key current and potential competitors" (1990, p2I-22). Previous studies highlight the short term thinking of new ventures and argued the need for more long-term thinking and strategic competitive positioning (Robinson and Pearce 1984; Tarek and Bain 1990). 


\section{Market Dynamism}

Competition is seen as a key influencing factor for innovativeness (Utterback 1974; Kimberly and Evanisko 1981). Start-up and mature companies operating in environments characterized by dynamic competition are forced to create innovative products and services and innovations are correlated to risky actions to create superior performance (Barney 1991). More recent research explored a positive relationship between market orientation and innovation integrated in the amount of innovations implemented (Han, Kim and Srivastava 1998; Hurley \& Hult 1998; Lukas and Ferrell 2000). It seems that entrepreneurs and managers must scan the market more carefully in a highly competitive environment. However, market orientation by itself does not help to create value from market dynamism: it needs both management and knowledge creation capabilities (Lewrick 2007). Essential drivers might be management experience, management tenure, inter-organizational networks as well as the capability of organizational learning. Within this study market dynamism is defined as the change of technology, customer needs, and the actions of competitors. It is assumed that dynamic markets are unpredictable with regard to the competitive conditions.

\section{Hypotheses}

Two major hypotheses are outlined with respect to the correlations between the variables in the model. The first hypothesis addresses the correlation between customer orientation and radical innovations. As mentioned in the introduction, customer orientation is key for both start-up and maturecompaniesand is a major element ofmarketorientation. Hence, we can state the first hypothesis to be tested as:

HI: Customer Orientation is positively correlated to radical innovations

In contrast to $\mathrm{HI}$ the second hypothesis stresses the correlation between competitor orientation and innovativeness. Referring to the introduction and reviewed literature a strong competitor orientation might lead to metoo products or only improvements in current products or services. However, the concept of competitor orientation includes also the evaluation of the strengths and weaknesses of the competition. Therefore, competitor information embraces the process of collecting and analyzing competitor information. Thus the second hypothesis is stated as:
$\mathrm{H}$ 2: Competitor Orientation is related positively to incremental innovations.

\section{Data Collection}

Over 200 CEOs and Managing Directors of innovative and technology driven companies in the hightechnology cluster around Munich responded to an online questionnaire about their market orientation to innovation as part of a larger survey to understand factors influencing innovation and success. Three parts of the questionnaire were intended to survey the customer orientation, competitor orientation and the market and competitor environment with 16 key statements. The respondents rated the extent of use on a seven point scale from I, no extent, to 7 , a great extent. The questions were derived from various literature (Narver and Stanley 1990; Kwaku, 2005; Kwaku et al. 2005; Jaworski and Kohli 1993) to apply verified and tested questions. In addition, one part of the questionnaire had been designed to explore incremental and radical innovation performance in relation to sales increases and customer satisfaction. Organizational information on sector, core competences, years in business, number of employees, sales, and sales increases were also collected in the questionnaire.

Statements on customer orientation were related to collection, analysis and monitoring of customer orientation as well as link to operational and strategic business planning. These were:

- We regularly meet customers to learn about their current potential needs for new products.

-We constantly monitor and reinforce our understanding of the current and future needs of customers.

- We have a thorough knowledge about emerging customers and their needs.

- Information about current and future customers is integrated in our plans and strategies.

- We regularly use research techniques such as focus groups, surveys, and observation to gather customer information.

-We have developed effective relationships with customers and suppliers to fully understand new technological development that affect customer's needs.

-We systematically process and analyze customer information to fully understand their implication for our business. 
To explore the degree of competitor orientation four key questions were developed to learn more about data collection, knowledge and information sharing and implications of competitor orientation. These were:

- We regularly collect and integrate information about the products and strategies of our competitors.

- We systematically collect and analyze information about potential competitor activities.

- Managers in this company regularly share information about current and future competitors within the company.

- Our knowledge of current and potential competitors' strengths and weaknesses is very thorough.

The third section aimed at identifying factors triggered by the market and competitive environment that influence the companies' strategy and actions. These were:

- The actions of local and foreign competitors change quite rapidly in your major markets.

- Technology changes in your industry were rapid and unpredictable.

- The market competitive conditions were highly unpredictable.

- Customers' product preferences change quite rapidly.

- Changes in customers' need were quite unpredictable.

In addition, key statements were developed to identify the impact of incremental and radical innovation on sales, and to explore the customer satisfaction with incremental and radical innovations produced. These were:

- \% of Total Sales from incremental products/services introduced by your company in a typical year.

-\% of Total Sales from radical products/services introduced by your company in a typical year.

- Customer satisfaction with incremental innovations.

- Customer satisfaction with radical innovations.

Finally, the innovation performance was measured employing a measure of the amount of radical and incremental innovations realized in a typical year in all areas, that is, product, process, service, administrative, and technical aspects of the business.

\section{Analysis of Data}

Before the data set was examined verification and data cleaning was applied to form a reliable set of cases. This reduced the number of usable responses to 171 . Companies were then clustered into start-ups and mature companies (55 start-up and 116 mature companies). Start-up companies were defined as new ventures which had been in business for less than 2 years. Mature companies were taken to be those which had been successful in the market for more than 2 years. The link between the different characteristics of market orientation and innovativeness was established by examining correlation matrices. Factor analysis was applied as a data reduction technique, to create new variables to determine the effect on the innovation measures of variations in the market domains.

\section{Results}

The correlation between the market orientation variables and the number and type of innovation score, representing the number and type of innovations, is laid out in Table I. There are a number of significant correlations between specific customer orientation variables and the incremental, radical and total innovation score. In particular, all the customer orientation variables but one have a strong correlation with radical innovation. Some dimensions of competitor orientation were significantly positively correlated with the number of incremental innovations in areas, such as, competitor orientation strategy and competitor orientation information. In contrast, there appeared to be little evidence of a correlation between competitor orientation and radical innovation. The correlations between the market and competitive environment variables and innovativeness were also mainly significantly positively correlated. 


\begin{tabular}{|c|c|c|c|}
\hline C orrelations / $\mathrm{n}=171$ & $\begin{array}{l}\text { Incremental } \\
\text { innovation } \\
\text { score }\end{array}$ & $\begin{array}{l}\text { Radical } \\
\text { innovation } \\
\text { score } \\
\end{array}$ & $\begin{array}{l}\text { Total } \\
\text { innovation } \\
\text { score } \\
\end{array}$ \\
\hline Customer O rientation Potential N eeds & 0.056 & $0.200(* *)$ & $0.151(*)$ \\
\hline Customer O rientation $\mathrm{M}$ onitoring & 0.138 & $0.224(* *)$ & $0.213(* *)$ \\
\hline Customer Orientation K nowledge & $0.274(* *)$ & $0.260(* *)$ & $0.313(* *)$ \\
\hline Customer Orientation Strategy & 0.125 & $0.210(* *)$ & $0.197(* *)$ \\
\hline Customer O rientation Research Techniques & $0.330(* *)$ & $0.290(* *)$ & $0.363(* *)$ \\
\hline Customer Orientation Relationships & $0.296(* *)$ & $0.372(* *)$ & $0.392(* *)$ \\
\hline Customer O rientation Information & $0.182(*)$ & $0.189(*)$ & $0.218(* *)$ \\
\hline Competitor Orientation Strategy & $0.154(*)$ & 0.041 & 0.114 \\
\hline Competitor Orientation Potential & 0.107 & -0.037 & 0.040 \\
\hline Competitor Orientation Information & 0.065 & 0.054 & 0.069 \\
\hline Competitor Orientation K nowledge & $0.230(* *)$ & 0.051 & $0.164(*)$ \\
\hline M arket \& Competitive Environment : Changes A ction & 0.131 & $0.194(* *)$ & $0.190(* *)$ \\
\hline M arket $\&$ Competitive Environmt: Changes Technology & $0.224(* *)$ & $0.162(*)$ & $0.226(* *)$ \\
\hline $\begin{array}{l}\text { M arket } \& \text { Competitive Environment: Conditions } \\
M \text { arket } \& \text { Competitive Environment: Customer }\end{array}$ & 0.140 & 0.125 & $0.155\left(^{*}\right)$ \\
\hline $\begin{array}{l}\text { Preferences } \\
\text { M arket \& Competitive E Environment: Changes }\end{array}$ & 0.054 & $0.249(* *)$ & $0.178(*)$ \\
\hline Customer N eeds & 0.060 & 0.116 & 0.103 \\
\hline
\end{tabular}

Table I: Correlations: Market Variables and Innovativeness

It should be noted that the correlations in Table I are relatively low. However, it is possible to suggest some implications arising from these results. The strong correlations between customer orientation and radical innovation indicates that a highly customer centric approach is necessary to create radical innovations. This gives some support to Von Hippel (2005) who highlights the fact that "some 75 per cent of all commercial innovations fail, yet we stick to the traditional ways of R\&D". He emphasized that many innovations are triggered from outside a company. Customers of products often are ahead of the trend and are able to develop radical product and service innovations.

Kim and Mauborgne (2005:42) descried a strong competitor orientation occurring when "the value curve converges with its competitors [...] this signals slow growth". They argue that value innovation occurs when an organization aims at creating new and uncontested market space, which they term a blue ocean strategy, and avoids direct competition with their competitors, which they term a red ocean strategy. Similarly, Williams et al. (20II) presented a VFBOP model to utilize a value innovation blue ocean strategy in 'base of the pyramid' emerging markets to create market demand where a lack of competitors exists. The correlations between competitor orientation strategy and competitor orientation knowledge with incremental innovation support the argument that competitor orientation leads to a "red ocean" strategy. Within the market and competitive environment, both the correlation between changes action and customer preferences indicate a strong relationship to radical innovation.

Factor analysis with varimax rotation was used to create factor scores from the sixteen questions. Four factors were formed which have been labeled customer centric, competitor orientation, market dynamism and customer intelligence (see Table 2). Both customer centric and 
customer intelligence were proxies for customer orientation. These variables accounted for $21.6 \%, 17.7 \%$, $16.4 \%$ and $11.1 \%$ respectively, (see the rotated component matrix displayed in Table 2). The Kaiser-Meyer-Olkin
Measure of Sampling Adequacy was 0.73 and Bartlett's test of Sphericity was statistically significant $(P<0.001)$ indicating that the application of factor analysis was successful.

\begin{tabular}{|c|c|c|c|c|}
\hline \multirow[t]{2}{*}{ Rotated Component M atrix(a) } & \multicolumn{4}{|c|}{ Component } \\
\hline & 1 & 2 & 3 & 4 \\
\hline Customer Orientation K nowledge & 0.857 & & & \\
\hline Customer Orientation Strategy & 0.829 & & & \\
\hline Customer Orientation Relationships & 0.776 & & & \\
\hline Customer Orientation Potential N eeds & 0.762 & & & \\
\hline Customer Orientation M onitoring & 0.721 & & & \\
\hline Competitor Orientation Potential & & 0.889 & & \\
\hline Competitor Orientation Strategy & & 0.817 & & \\
\hline Competitor Orientation Information & & 0.779 & & \\
\hline $\begin{array}{l}\text { Competitor Orientation } K \text { nowledge } \\
\text { M arket } \& \text { Competitive Environment Changes }\end{array}$ & & 0.748 & & \\
\hline $\begin{array}{l}\text { Technology } \\
\text { M arket \& Competitive Environment Changes }\end{array}$ & & & 0.812 & \\
\hline Customer N eeds & & & 0.796 & \\
\hline $\begin{array}{l}M \text { arket } \& \text { Competitive Environment Conditions } \\
M \text { arket } \& \text { Competitive Environment Customer }\end{array}$ & & & 0.790 & \\
\hline & & & 0.662 & 0.366 \\
\hline Action & & 0.342 & 0.456 & 0.391 \\
\hline Customer Orientation Research Techniques & & & & 0.791 \\
\hline Customer Orientation Information & 0.350 & & & 0.754 \\
\hline
\end{tabular}

Table 2: Rotated Component Matrix (component I - customer centric, component 2 - competitor orientation, component 3 - market dynamism, component 4 - customer intelligence)

The differences between innovativeness of start-up and mature companies and their respective factor scores are shown in Table 3. 


\begin{tabular}{|c|c|c|c|c|c|c|c|c|}
\hline & & 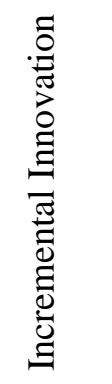 & 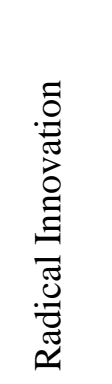 & 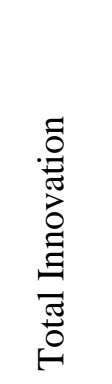 & 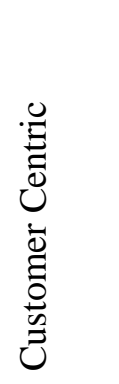 & 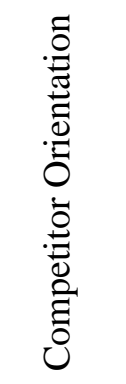 & 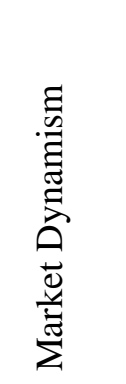 & 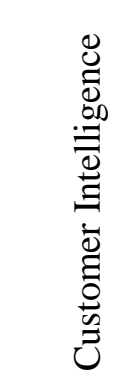 \\
\hline \multirow[t]{2}{*}{ Start-up } & M ean & 1.745 & 1.909 & 1.836 & 0.147 & 0.140 & 0.172 & -0.187 \\
\hline & Std. Dev. & 0.751 & 0.752 & 0.714 & 0.722 & 1.004 & 1.134 & 0.744 \\
\hline \multirow[t]{2}{*}{ M ature } & M ean & 2.026 & 1.672 & 1.897 & -0.070 & -0.067 & -0.081 & 0.088 \\
\hline & Std. Dev. & 0.625 & 0.682 & 0.664 & 1.104 & 0.996 & 0.924 & 1.093 \\
\hline \multirow[t]{2}{*}{ Total } & M ean & 1.936 & 1.749 & 1.877 & 0.000 & 0.000 & 0.000 & 0.000 \\
\hline & Std. Dev. & 0.679 & 0.712 & 0.679 & 1 & 1 & 1 & 1 \\
\hline
\end{tabular}

Table 3: Startup and mature companies compared

From Table 3 it is clear that start-up companies have more radical innovations but fewer incremental innovations than mature companies (these differences are significant at the $5 \%$ level). Total innovative activity is fairly similar. Start-up companies appear more customer centric and customer orientated and seem more concerned about market dynamism than mature companies. However, the reverse is the case for customer intelligence. It was felt that the originally low correlations with competitor orientation may be explained by reference to the age of the company. Comparing the correlations of the four components identified in the factor analysis with innovation by company stage shows that this may indeed be the case. This is demonstrated in Table 4 which shows the results of the factor components correlated with innovativeness for both start-up and mature companies.

\begin{tabular}{|c|c|c|c|}
\hline Start-up /n=55 & $\begin{array}{l}\text { Incremental } \\
\text { innovation score }\end{array}$ & $\begin{array}{l}\text { Radical } \\
\text { innovation score }\end{array}$ & $\begin{array}{l}\text { Total innovation } \\
\text { score }\end{array}$ \\
\hline Customer Centric & $0.379(* *)$ & 0.229 & $0.338(* *)$ \\
\hline Competitor Orientation & $0.514(* *)$ & $0.456(* *)$ & $0.542(* *)$ \\
\hline M arket Dynamism & 0.014 & 0.010 & 0.013 \\
\hline Customer Intelligence & $0.404(* *)$ & $0.288(*)$ & $0.386(* *)$ \\
\hline \multicolumn{4}{|l|}{ M ature/ $n=116$} \\
\hline Customer Centric & $0.196(*)$ & $0.292(* *)$ & $0.287(* *)$ \\
\hline $\begin{array}{l}\text { Competitor Orientation } \\
\text { M arket D ynamism }\end{array}$ & $\begin{array}{l}-0.054 \\
0.261(* *)\end{array}$ & $\begin{array}{l}-0.297(* *) \\
0.285(* *)\end{array}$ & $\begin{array}{l}-0.207(*) \\
0.320(* *)\end{array}$ \\
\hline Customer Intelligence & 0.070 & $0.245(* *)$ & $0.186(*)$ \\
\hline \multicolumn{3}{|c|}{ ** Correlation is significant at the 0.01 level (2-tailed). } & \\
\hline
\end{tabular}

Table 4: Correlations: Categories Start-up and Mature Companies

ISSN: 07I8-2724. (http://www.jotmi.org) 
Being customer centric was positively correlated with incremental innovation for both start-up and mature companies but it was only positively correlated with radical innovation for mature companies. This gives some partial support to hypothesis $\mathrm{HI}$ Within the group of start-up companies a strong correlation between competitor orientation and both incremental and radical innovations was observed. This suggests that companies in an early stage tend to focus on benchmarking and analyzing competitors, which leads them to innovate. In contrast, for mature companies there is a negative correlation to competitor orientation. A competitor orientation for mature companies appears to be counter productive when it comes to innovations and is significantly so for radical innovations. This supports the $\mathrm{H} 2$ hypothesis.

Another area of difference was the impact of the market dynamism. For start-up companies the overall dynamic of the market had no relevance, but for mature companies this dynamism was strongly related to both incremental and radical innovations. It suggests that a dynamic environment forces mature companies to put more emphasis on creating innovative products and services. There is also a clear contrast to be observed between start-up and mature companies in the area of customer intelligence. For startups, customer intelligence had an impact on the amount of radical and incremental innovations realized, however, for mature companies this influenced only radical innovations.

To determine the degree to which the constructed variables of customer centric, market dynamism, customer intelligence and competitor orientation make to fostering innovative activity, ordinary least square regression models were constructed for all companies; both startup and mature companies. The natural logarithm of total, incremental and radical innovation was taken as the distributions of these were skewed toward zero and taking natural logarithms successfully transformed these dependent variables to more normal distributions. These models are displayed in Table 5. All the models were statistically significant and showed that the factors do explain a reasonable amount of the variation in innovative activity

\begin{tabular}{|c|c|c|c|c|c|c|c|c|c|}
\hline \multirow[t]{2}{*}{ Variable } & \multicolumn{3}{|c|}{ All Companies $(\mathrm{N}=171)$} & \multicolumn{3}{|c|}{ Start-up Companies $(\mathrm{N}=55)$} & \multicolumn{3}{|c|}{ M ature Companies $(\mathrm{N}=116)$} \\
\hline & 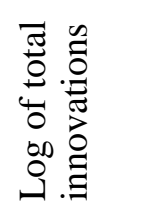 & 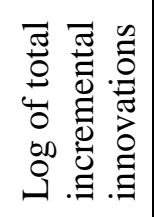 & 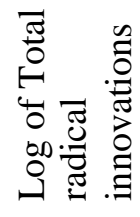 & 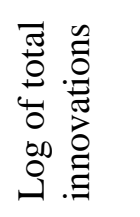 & 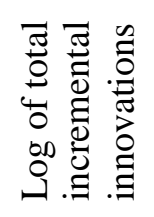 & 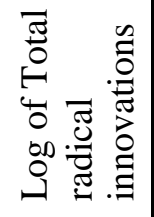 & 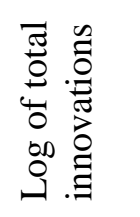 & 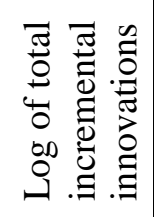 & 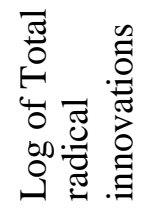 \\
\hline Constant & $\begin{array}{l}3.034 * * \\
(0.020)\end{array}$ & $\begin{array}{l}2.383^{* *} \\
(0.025)\end{array}$ & $\begin{array}{l}2.259 * * \\
(0.024)\end{array}$ & $\begin{array}{l}2.990 * * \\
(0.038)\end{array}$ & $\begin{array}{l}2.248^{* *} \\
(0.043)\end{array}$ & $\begin{array}{l}2.319 * * \\
(0.047) \\
\end{array}$ & $\begin{array}{l}3.050 * * \\
(0.023)\end{array}$ & $\begin{array}{l}2.447 * * \\
(0.029)\end{array}$ & $\begin{array}{l}2.225^{* *} \\
(0.028)\end{array}$ \\
\hline $\begin{array}{l}\text { Customer } \\
\text { Centric }\end{array}$ & $\begin{array}{l}0.078^{* *} \\
(0.020)\end{array}$ & $\begin{array}{l}0.073^{* *} \\
(0.025)\end{array}$ & $\begin{array}{l}0.099 * * \\
(0.024)\end{array}$ & $\begin{array}{l}0.069 \\
(0.053)\end{array}$ & $\begin{array}{l}0.0121^{* *} \\
(0.059)\end{array}$ & $\begin{array}{l}0.018 \\
(0.065)\end{array}$ & $\begin{array}{l}0.068 * * \\
(0.021)\end{array}$ & $\begin{array}{l}0.059 * * \\
(0.026)\end{array}$ & $\begin{array}{l}0.091 * * \\
(0.026)\end{array}$ \\
\hline $\begin{array}{l}\text { M arket } \\
\text { Dynamism }\end{array}$ & $\begin{array}{l}0.054^{* *} \\
(0.020) \\
\end{array}$ & $\begin{array}{l}0.047^{*} \\
(0.025) \\
\end{array}$ & $\begin{array}{l}0.064 * * \\
(0.024) \\
\end{array}$ & $\begin{array}{l}0.018 \\
(0.034) \\
\end{array}$ & $\begin{array}{l}0.029 \\
(0.039) \\
\end{array}$ & $\begin{array}{l}-0.004 \\
(0.042)\end{array}$ & $\begin{array}{l}0.075^{* *} \\
(0.025) \\
\end{array}$ & $\begin{array}{l}0.086^{* *} \\
(0.031) \\
\end{array}$ & $\begin{array}{l}0.074^{* *} \\
(0.031) \\
\end{array}$ \\
\hline $\begin{array}{l}\text { Customer } \\
\text { Intelligence }\end{array}$ & $\begin{array}{l}0.069 * * \\
(0.020) \\
\end{array}$ & $\begin{array}{l}0.041 \\
(0.025) \\
\end{array}$ & $\begin{array}{l}0.089 * * \\
(0.024) \\
\end{array}$ & $\begin{array}{l}0.059 \\
(0.056) \\
\end{array}$ & $\begin{array}{l}0.069 \\
(0.063)\end{array}$ & $\begin{array}{l}0.035 \\
(0.067) \\
\end{array}$ & $\begin{array}{l}0.044 * * \\
(0.021) \\
\end{array}$ & $\begin{array}{l}0.001 \\
(0.027)\end{array}$ & $\begin{array}{l}0.080^{* *} \\
(0.026) \\
\end{array}$ \\
\hline $\begin{array}{l}\text { Competitor } \\
\text { Orientation }\end{array}$ & $\begin{array}{l}0.012 \\
(0.020)\end{array}$ & $\begin{array}{l}0.034 \\
(0.025) \\
\end{array}$ & $\begin{array}{l}-0.018 \\
(0.024) \\
\end{array}$ & $\begin{array}{l}0.114^{* *} \\
(0.041) \\
\end{array}$ & $\begin{array}{l}0.102^{* *} \\
(0.047) \\
\end{array}$ & $\begin{array}{l}0.131^{* *} \\
(0.051) \\
\end{array}$ & $\begin{array}{l}-0.032 \\
(0.023) \\
\end{array}$ & $\begin{array}{l}0.002 \\
(0.029) \\
\end{array}$ & $\begin{array}{l}-0.078^{* *} \\
(0.029) \\
\end{array}$ \\
\hline $\begin{array}{l}\text { A djusted } \\
\mathrm{R}^{2}\end{array}$ & $15.7 \%$ & $7.9 \%$ & $16.4 \%$ & $23.9 \%$ & $22.9 \%$ & $12.9 \%$ & $19.0 \%$ & $7.9 \%$ & $25.5 \%$ \\
\hline
\end{tabular}

Table 5: Coefficients of Regression models with standard errors in parenthesis 
The adjusted R2 of incremental innovations for mature companies is low compared to that of the start-up companies. This suggests that start-up companies may indeed be focusing on market orientation and incremental innovation while mature companies focus more on radical innovations. At the total level the components of customer centric, market dynamism and customer intelligence are positively correlated to innovation. In terms of incremental innovation only the component market dynamism correlates significantly at the $5 \%$ level. For start-up companies, only customer orientation has a positive correlation across all innovations, while customer centric correlates significantly for incremental innovations. With mature companies, customer centric and market dynamism correlate significantly for all innovations. Customer intelligence correlates significantly with radical innovation while competitor orientation is not significant for incremental innovation but has a significant negative effect for radical innovation.
In Table 6 the correlation of customer satisfaction with radical and incremental innovations is confirmed. This suggests that innovations have a positive impact on customer satisfaction and retention. In addition, where there is radical innovation, there is a positive correlation with customer satisfaction for both radical and incremental innovations. It may be that customers recognize the radical innovations of a company and this influences their propensity to buy other products by the same company which only provide incremental improvements to existing offerings. As a result, the enhancement to reputation gained from the company offering innovative breakthrough products also improves the sales volume of the less innovative products.

\begin{tabular}{|l|lll|}
\hline Correlations / A II Companies / $n=171$ & $\begin{array}{l}\text { Incremental } \\
\text { innovation } \\
\text { score }\end{array}$ & $\begin{array}{l}\text { Radical } \\
\text { innovation } \\
\text { score }\end{array}$ & $\begin{array}{l}\text { Total } \\
\text { innovation } \\
\text { score }\end{array}$ \\
\hline $\begin{array}{l}\text { Innovation Performance (Incremental) \% Sales } \\
\text { Innovation Performance (Radical) \% Sales } \\
\text { Innovation Performance (Incremental) Customer }\end{array}$ & $0.199\left(^{* *}\right)$ & 0.030 & 0.134 \\
$\begin{array}{l}\text { Satisfaction } \\
\text { Innovation Performance (R adical) Customer }\end{array}$ & $0.257(* *)$ & $0.540\left(^{* *}\right)$ & $0.468(* *)$ \\
Satisfaction & $0.246(* *)$ & 0.081 & $0.191(* *)$ \\
\hline $\begin{array}{l}* * \text { Correlation is significant at the 0.01 level (2-tailed). } \\
* \text { Correlation is significant at the 0.05 level (2-tailed). }\end{array}$ & $0.354(* *)$ & $0.336(* *)$ \\
\hline
\end{tabular}

Table 6: Correlations of Innovation Performance

\section{Conclusion}

Exploring both start-up and mature companies, this research focused on market orientation and its impact on producing either incremental or radical innovations. The paper contributes to knowledge in a number of areas. The study identifies a generally positive relationship between a number facets of customer orientation and across innovation types. In particular, all elements of customer orientation apart from one have a strong relationship with radical innovation. However, the component customer centric derived from the factor analysis only demonstrated a strong relationship with radical innovation in mature companies. As a result, the hypothesis $(\mathrm{HI})$ that Customer Orientation is related positively to radicial innovations can be accepted for mature companies but has to be rejected for start-up companies.

The research results suggest that for mature companies a strong competitor orientation leads to imitation and does not foster more fundamental invention and innovation. For start-up companies the competitor orientation appears to help identify competitive opportunities that facilitate the launching of new products or services. As a result the 
hypothesis $(\mathrm{H} 2)$ Competitor Orientation is related positively to incremental innovations can be accepted for start-up companies and must be rejected for mature companies.

The results of this study reveal that there are differences between start-up and mature companies in respect to market orientation and innovation. A number of recommendations and observations flow from these results. Start-up companies should observe and analyze competitor's activities in the process of bringing ideas to market. This might be already included in the development of the initial business plan and it should help to bring incremental innovations to market success. In contrast, to stay innovative and to continuously generate the new ideas that bring market success an orientation towards competitors might not be the ideal strategic focus for mature companies. Knowing the strategy of competitors might enhance the market intelligence of a mature organization but it does not lead to innovation success, and appears to mitigate against the development of radical innovations.

As stated earlier in this paper Kim and Mauborgne (2005:42) argue that value innovation occurs when an organization avoids direct competition with their competitors but aims instead at creating new and uncontested market space, which they term a blue ocean strategy. It is probable that more mature companies are operating in more mature markets. It could be argued therefore that it is unlikely that mature companies will find this uncontested market space through a competitor orientation but only through radical innovations based on a customer orientation. Start up companies operating in less mature markets may well find uncontested space in the market through an analysis of competitor activity in what may be a less competitive landscape.

Having identified some significant differences between start-up and mature companies with respect to market orientation and its affect on innovation we suggest that further research is required to explore the transformation process of growing companies. Observing the actual changes and influencing factors might help to foster a deeper understanding of the different perceptions around market orientation and its relationship to successful innovation.

\section{About the Authors}

Dr Michael Lewrick is a graduate of from Napier University Edinburgh and holds a MBA from Bristol Business School. He studied - in New York, Munich and Nice - Business Administration with an emphasis on IT and organization. His research interests centres on the management issues related to the development and commercialisation of technological and business model innovation. Specific areas of focus include developing capabilities for innovativeness and business success. A number of publications have been produced in this area. Currently Dr Lewrick holds a Senior Strategy Manager position at Swisscom, Zurich. His expertise centres in the development of go-tomarket concepts, M\&A transactions, growth strategies, investment steering and the management of innovations.

Dr. Maktoba Omar is a Reader of International Marketing Strategy at Edinburgh Napier University, Scotland, member of the research committee, and a visiting lecturer/ researcher at Harbin University, Tsinghua University (China), and Munich University of Applied Sciences (Germany). She has published in a number of national and international peer reviewed academic journals as well as presented at conferences and workshops. Current research interests focus on globalisation, international strategy and marketing policy. m.omar@napier.ac.uk

Prof. Robert L. Williams, Jr., is an Assistant Professor of Marketing at Saint Mary's College, Notre Dame, Indiana, USA. He has published in peer-reviewed journals such as Journal of Product \& Brand Management (Emerald Literati 2008 Award for Excellence international) and Journal of Brand Management as well as presented at numerous conferences and workshops. After 20 years as a practitioner in Fortune 50/500 companies, his current academic research interests focus on competitive advantage, branding, innovation, Higher Education, and market entry strategies. rlwjr@saintmarys.edu 


\section{References}

AUDRETSCH, D. (200I), "Research Issues Relating to Structure, Competition, andPerformance ofSmall TechnologyBased Firms," Small Business Economics, I6, I, 37-5I.

BARNEY, J. (1991), "Firm Resources and Sustained CompetitiveAdvantage,”Journal ofManagement, 17,99-I20.

BENNETT, R. C. and Cooper, R. (1979), "Beyond the Marketing Concept”, Business Business Research, 35, 93-I03.

BIGLIARDI, B., Colacino, P. and Dormio, A. (20II), Innovative Characteristics of Small and Medium Enterprises, Journal of Technology Management \& Innovation, Vol 6, No 2, pp. 83-93.

CANO, C.R., Carrillat, F. and Jaramillo, F. (2004), “A Meta-Analysis of the Relationship between Market Orientation and Business Performance: Evidence from Five Continents," International Journal of Research in Marketing, 21, 179-100.

CLAYTON C, and Bower, J. (1996), "Customer Power, Strategic Investment, and Failure of Leading Firms," Strategic Management Journal, 17, 197-218.

COHEN, W. M and Klepper, S. (1992), "The Trade off between Firm Size and Diversity in the Pursuit of TechnologicalProgress,"SmallBusinessEconomics, 4, I, I-I4.

DESHPANDÉ, R. (1999) Developing a Market Orientation. Thousand Oaks, CA: Sage Publications.

DRUCKER, P. (1954), The Practice of Management. New York: Harper.

GAINER, B. and Padanyi, P. (2005), "The Relationship between Market-Oriented Activities and MarketOriented Culture: Implications for the Development of Market Orientation in non-Profit Service Organizations," Journal of Business Research, 58, 854-862

GATIGNON, H., Tushman, M., and Anderson, W. (2002), "A Structural Approach to Assessing Innovation: Construct Development of Innovation Locus, Type, and Characteristics," Management Science, Vol. 48, II03-II 22
GATIGNON, H. and Xuereb, J-M (1997), "Strategic Orientation of the Firm and New Product Performance," Journal of Marketing Research, XXXIV, 77-90

GIANNOPOULOU, E. Yström, A., Ollila, S; Fredberg, T; and Elmquist, T. (2010), Implications of Openness: A Study into (AII) the Growing Literature on Open Innovation, Journal of Technology Management \& Innovation, Vol. 3, No. 3, pp.162-180

GREENLY, G. E. (1995), “Forms of market orientation in UK companies,” Journal of Management Studies, 32, I, 47-66

HAN, J., Kim, N. and Srivastava, R. (1998), "Market Orientation and Organizational Performance: Is Innovation a Missing Link?” Journal of Marketing, 62, 30-45

HOOLEY, G., Cox, T., Fahy, J., Shipley, D. Beracs, J.; Fonfara, K. and Snoj, B. (2000) "Market Orientation in the Transition Economies of Central Europe: Tests of the Narver and Slater Market Orientation Scales," Journal of Business Research, 50, (December), 273-285

HULT, G. T.; Ketchen, D. J. Slater, S. F. (2005), Market Orientation and Performance: An Integration of Disparate Approaches, Strategic Management Journal, 26, II73-II8I

HUNT, S. and Lambe, J (2000), “Marketing's contribution to business strategy: market orientation, relationship marketing and resource-advantage theory," International Journal of Management Reviews, 2, I, 17-43

HURLEY, R. F. and Hult, T. (1998), “Innovation, Market Orientation and Organizational Learning: An Integration and Empirical Examination,”Journal of Marketing 62, (July), 42-54

HYVONEN, S. and Tuominen, M. (2006), “Entrepreneurial Innovations, Market-Driven Intangibles and Learning Orientation: Critical Indicators for Performance Advantages in SMEs," International Journal of Management and Decision Making, 7, 6, 643-660

JAWORSKI, B.J. and Kohli, A. (1993), "Market Orientation: Antecedents and Consequences", Journal of Marketing," 57, (July), 53-70 
KAHN, K. B. (200I), "Market Orientation, Interdepartmental Integration, and Product Development Performance,"Journal of Product Innovation Management, $18,5,3 \mid 4-23$

KARA, A., Spillan, J.E. and Oscar W. D. (2005), "The Effect of a Market Orientation on Business Performance: A study of Small-Sized Service Retailers using MARKOR scale,"Journal of Small Business Management, 43, 2, 105-18

KIM,C.andMauborgne, R. (2005), BlueOceanStrategy:How to CreateUncontestedMarketSpaceandMakeCompetition Irrelevant, Boston: Harvard Business School Press

KIMBERLY, J. R. and Evanisko, J.. (198I), “Organizational Innovation: The influence of Individual, Organizational, and Contextual Factors on Hospital Adoption of Technological and Administrative Innovations," Academy of Management Journal, 24 (Dec), 689-713

KOHLI, Ajay K. and Jaworski, B. (1990), "Market Orientation: The Construct, Research Propositions, and Manageriallmplications”,JournalofMarketing,54(April), I-8

KWAKU ATUAHENE-GIMA (1996), "Market Orientation and Innovation", Journal of Business Research, 35, 93-103

KWAKU ATUAHENE-GIMA (2005), "Resolving the Capability-Rigidity Paradox in New Product Innovation," Journal of Marketing, 69 (October), 6I-83

KWAKU ATUAHENE-GIMA; Slater, S. and Olson, E.M. (2005), "The Contingent Value of Responsive and Proactive Market Orientations on New Product Program Performance" Journal of Product Innovation Management 22 (6), 464-482

LANGERAK, F. (200I), "Effects of Market Orientation on the Behaviours of Salespersons and Purchasers, Channel Relationship, and the Performance of Manufacturers," International Journal of Research in Marketing, 18, (September), 22I-234

LAWTON, L. and Parasuraman, A., (1980), "The Impact of the Marketing Concept on New Product Planning," Journal of Marketing, 44, 19-25
LEONARD-BARTON, D. and Doyle, J.L. (1996), "Commercializing Technology: Imaginative Understanding of User Needs," in Engines of Innovation, Richard S. Rosenbloom and William J. Spencer, eds. Boston, Harvard Business School Press, 177-208

LEVITT, Theodore (1960), Marketing Myopia, Harvard Business Review, 38, 4, 45-57

LEWRICK, M. (2004), “Customer Relationship Management: Applying Relationship Management to Deliver More Value to Clients and Partners of the Automotive Industry Development Centre in South Africa," masters dissertation, Bristol Business School

LEWRICK, M. (2007), "Changes in Innovation Styles: Comprehensive Study of the Changes in Innovation Styles to Identify the Causes and Effects of Different Influencing Factors and Capabilities to Create a General Innovation Pattern" doctoral dissertation, Edinburgh Napier University Business School, Edinburgh Napier University

LEWRICK, M. (2009) Introduction of an Evaluation Tool to Predict the Probability of Success of Companies: The Innovativeness, Capabilities and Potential Model (ICP), Journal of Technology Management \& Innovation, Vol. 4, No. I, pp.33-47

LUKAS, B. and Ferrell, O. (2000), "The Effect of Market Orientation on Product Innovation." Journal of the Academy of Marketing Science, 28(2), 239-247

NARVER, C. and Stanley F. (1990), "The Effect of a Market Orientation on Business Profitability," Journal of Marketing, 54, (October), 20-35

ROSANNA, G. and Calantone, R. (2002) "A critical look at technological innovation typology and innovativeness terminology: A literature review", Journal of Product Innovation Management, March, 19(2): II0-132

ROBINSON, R. Jr., and Pearce, J (1984), "Research Thrusts in Small Firm Strategic Planning," Academy of Management Review, 9 (I), 128-137

RUEKERT, Robert W. (1992), "Developing a Market Orientation: An Organizational Strategy Perspective," International Journal of Research in Marketing, 9, 225-245 
SLATER, S. and Narver, C. (1994), "Marketing Orientation, Customer Value and Superior Performance," Business Horizons, 37, 22-28

TAREK, S. and Bain, C. (1990), "Making Small Business Planning Easier: Microcomputers Facilitate the Process," Journal of Accountancy, 170, I, 53-58

TIDD, J., Bessant, J. and Pavitt, K. (2003), Managing Innovation, Chichester: John Wiley and Sons

UTTERBACK, M. (1974) "Innovation and the Diffusion of Technology,” Science, 83, 4125, (February), 620-626

UTTERBACK, M. (1996), Mastering the Dynamics of Innovation. Boston, MA: Harvard Business School Press

VERBEES, F. and Meulenberg, M.T. (2004) "Market Orientation, Innovativeness, Product Innovation, and Performance in Small Firms," Journal of Small Business Management, 42, 2, $134-154$

VON HIPPEL, E. (2005), Democratizing Innovation, Cambridge MA: The MIT Press.

WILLIAMS, R., Omar, M. and Ensor, J. (2011), "Sourcing and Selling: The Value Flame at the Base of the Pyramid", Marketing Intelligence \& Planning, Vol. 29, No.3

WREN, B. (1997), "The Market Orientation Construct: Measurement and scaling issues," Journal of Marketing Theory and Practice, 15, 3, 31-54

ZHUO, Z., Yim, C. and K. Tse (2005), "The Effects of Strategic Orientations on Technology- and Market-Based Breakthrough Innovations," Journal of Marketing, 69, 42-60 
J. Technol. Manag. Innov. 20I I,Volume 6, Issue 3 